\title{
FAKTOR-FAKTOR YANG BERPENGARUH TERHADAP EFISIENSI USAHA AYAM SENTUL DI KABUPATEN CIAMIS
}

\author{
Oleh \\ AGUS YUNIAWAN ISYANTO \\ FAKULTAS PERTANIAN UNIVERSITAS GALUH CIAMIS \\ e-mail : gus_yus69@yahoo.com \\ SUDRAJAT \\ FAKULTAS PERTANIAN UNIVERSITAS GALUH CIAMIS \\ e-mail :sudrajat@unigal.ac.id \\ MOHAMAD ISKANDAR \\ BAPPEDA KABUPATEN CIAMIS
}

\begin{abstract}
Abstrak
Penelitian ini dilaksanakan dengan tujuan untuk mengetahui: (1) Tingkat efisiensi usaha ayam Sentul di Kabupaten Ciamis, dan (2) Faktor-faktor yang berpengaruh terhadap efisiensi usaha ayam Sentul di Kabupaten Ciamis.

Penelitian dilaksanakan di Kabupaten Ciamis dengan jumlah sampel penelitian sebanyak 36 peternak. Data yang digunakan terdiri atas data primer dan sekunder. Analisis faktor-faktor yang berpengaruh terhadap efisiensi usaha ayam Sentul dilakukan dengan menggunakan persamaan regresi linier berganda.

Hasil penelitian menunjukkan: (1) Peternak yang inefisien dalam melaksanakan usaha ayam Sentul $(\mathrm{R} / \mathrm{C}<1)$ sebanyak 13 orang $(36,11 \%)$, impas $(\mathrm{R} / \mathrm{C}=1)$ sebanyak 1 orang $(2,78 \%)$, dan efisien $(\mathrm{R} / \mathrm{C}>1)$ sebanyak 22 orang $(61,11 \%)$, dan (2) Faktor-faktor yang berpengaruh terhadap efisiensi usaha ayam Sentul adalah produktivitas, jumlah kepemilikan ayam, dummy pelatihan, pendidikan dan pengalaman. Efisiensi teknis, umur dan jumlah anggota keluarga tidak berpengaruh signifikan terhadap efisiensi usaha ayam Sentul.
\end{abstract}

Kata Kunci: Efisiensi, Usaha, Ayam Sentul

\section{PENDAHULUAN}

Laju pertambahan penduduk yang cukup tinggi menyebabkan kebutuhan terhadap pangan semakin meningkat (Jaelani, dkk., 2013). Pengembangan ternak ayam lokal sebagai produk pangan komplemen dalam penyediaan daging unggas dewasa ini memiliki prospek yang cukup baik (Hartono, dkk., 2013).

Perunggasan telah menjadi usaha yang penting bagi peternak kecil dan mempunyai kontribusi yang tinggi terhadap perekonomian suatu negara (Aboki, et al, 2013). Salah satu jenis unggas tersebut adalah ayam pedaging yang memiliki peranan penting dalam memenuhi kebutuhan masyarakat terhadap daging (Rohmad, 2013). Daging dan telur ayam merupakan sumber protein hewani yang banyak dikonsumsi masyarakat karena mudah didapat, kandungan gizi tinggi dan harga terjangkau. Permintaan terhadap daging dan telur ayam akan terus meningkat sejalan dengan meningkatnya jumlah penduduk, tingkat pendapatan serta kesadaran akan gizi baik (Muharlien dan Nurgiartiningsih, 2015).

Permasalahan utama dalam budidaya ayam kampung secara intensif adalah mahalnya harga pakan yang memenuhi syarat kebutuhan ayam untuk tumbuh secara maksimal, sementara produktivitas rendah. Permasalahan lain adalah sulitnya memperoleh bibit unggul karena belum banyak yang mengusahakan bibit ayam lokal dalam jumlah besar (Iskandar, 2010). 


\section{AIMBAR AGRIBISNIS \\ ISSN 2460-4321 \\ Volume 1 - Nomor 3 Juli 2016}

Salah satu cara untuk mengukur keberhasilan suatu usaha adalah dengan menggunakan analisis R/C (Santosa, dkk., 2013). Analisis R/C ini dapat digunakan untuk mengetahui efisiensi suatu usaha (Soekartawi, 2002 dalam Utami, dkk., 2014).

Penelitian ini dilaksanakan dengan tujuan untuk mengetahui: (1) Tingkat efisiensi usaha ayam Sentul di Kabupaten Ciamis, dan (2) Faktor-faktor yang berpengaruh terhadap efisiensi usaha ayam Sentul di Kabupaten Ciamis

\section{KAJIAN LITERATUR}

Cara untuk mengukur keberhasilan usaha salah satunya dengan analisis $\mathrm{R} / \mathrm{C}$ yang merupakan pembagian antara penerimaan dengan biaya produksi yang digunakan untuk menjalankan usaha. Besar kecilnya nilai $\mathrm{R} / \mathrm{C}$ tergantung pada penerimaan dan biaya produksi yang dikeluarkan untuk menjalankan usaha (Santosa, dkk., 2013).

Rasio penerimaan dan biaya $(R / C$ ratio $)$ adalah perbandingan antara total penerimaan dan total biaya. R/C dapat digunakan untuk menentukan efisiensi usaha dimana $\mathrm{R} / \mathrm{C}>1$ berarti efisien, $\mathrm{R} / \mathrm{C}=1$ berarti keuntungan bernilai nol, dan $\mathrm{R} / \mathrm{C}<1$ berarti inefisien (Soekartawi, 2002 dalam Utami, dkk., 2014). Mukarom (2009) dalam Taufik, dkk. (2013) menyatakan bahwa $\mathrm{R} / \mathrm{C}$ dapat digunakan untuk mengetahui efisiensi suatu usahatani.

\section{METODE PENELITIAN}

Penelitian dilaksanakan dengan menggunakan metode survai. Menurut Singarimbun (1989), penelitian survai adalah penelitian yang mengambil sampel dari satu populasi dan menggunakan kuesioner sebagai alat pengumpulan data yang pokok.

Responden peternak ayam Sentul dipilih secara acak sederhana dengan jumlah responden sebanyak 36 orang.

Data yang digunakan dalam penelitian ini terdiri atas data primer dan data sekunder. Data primer diperoleh melalui wawancara dengan menggunakan kuesioner yang telah dipersiapkan sebelumnya, sedangkan data sekunder diperoleh melalui penelusuran pustaka dan publikasi dari dinas/instansi terkait.
Variabel-variabel yang digunakan dalam penelitian ini adalah:

- Efisiensi usaha didekati dengan menggunakan $\mathrm{R} / \mathrm{C}$ yang merupakan rasio antara penerimaan dan biaya.

- Efisiensi teknis $\left(\mathrm{X}_{1}\right)$ adalah perbandingan antara faktor produksi (input) yang digunakan dalam usaha ayam Sentul dengan output yang dihasilkan per ekor ayam. Pengukuran efisiensi teknis dilakukan melalui perbandingan angka indeks input yang digunakan dengan angka indeks output yang dihasilkan. Nilai indeks efisiensi teknis antara 0 dan 1 , atau " $0<$ ET $<1$ ". Semakin mendekati nilai 1 maka efisiensi teknis yang dicapai peternak semakin tinggi dan sebaliknya

- Produktivitas faktor total $\left(X_{2}\right)$ adalah rasio antara output dengan seluruh input yang digunakan pada usaha ayam Sentul. Produktivitas faktor total ini diperoleh dengan membandingkan total nilai output dalam satuan rupiah $(\mathrm{Rp})$ dengan total nilai input yang digunakan dalam satuan rupiah (Rp).

- Umur $\left(X_{3}\right)$ adalah umur peternak ayam Sentul, dan diukur dalam satuan tahun (tahun).

- Pendidikan $\left(\mathrm{X}_{4}\right)$ adalah pendidikan formal yang pernah diikuti oleh peternak ayam Sentul, dan diukur dalam satuan tahun (tahun)

- Pengalaman beternak $\left(\mathrm{X}_{5}\right)$ adalah lamanya pengalaman peternak dalam usaha ayam Sentul, dan diukur dalam satuan tahun (tahun)

- Jumlah anggota keluarga $\left(\mathrm{X}_{6}\right)$ adalah banyaknya anggota keluarga peternak, dan diukur dalam satuan orang (orang).

- Jumlah kepemilikan ayam $\left(\mathrm{X}_{7}\right)$ adalah jumlah ayam Sentul yang dimiliki oleh peternak, dan diukur dalam satuan ekor (ekor)

- Pelatihan $\left(\mathrm{X}_{8}\right)$ merupakan variabel dummy yang bernilai 1 jika peternak terlibat dalam kegiatan pelatihan selama satu tahun terakhir, dan bernilai 0 jika tidak. 


\section{Faktor-Faktor Yang Berpengaruh Terhadap Efisiensi Usaha Ayam Sentul Di Kabupaten Ciamis \\ AGUS YUNIAWAN ISYANTO, SUDRAJAT, MOHAMAD ISKANDAR}

Efisiensi usaha ayam Sentul didekati dengan menggunakan persamaan berikut (Triastono, dkk., 2013):

$$
\begin{aligned}
& \mathrm{E}=\mathrm{R} / \mathrm{C} \\
& \mathrm{Dimana} \\
& \mathrm{E}=\text { Efisiensi usaha } \\
& \mathrm{R}=\text { Return (Penerimaan) }(\mathrm{Rp}) \\
& \mathrm{C}=\operatorname{Cost} \text { (Biaya) }(\mathrm{Rp})
\end{aligned}
$$

Jika $\mathrm{R} / \mathrm{C}>1$ berarti efisien, $\mathrm{R} / \mathrm{C}=1$ berarti keuntungan bernilai nol, dan $\mathrm{R} / \mathrm{C}<1$ berarti inefisien (Wibowo, dkk., 2013). Semakin besar nilai R/C, maka semakin besar tingkat efisiensinya (Ibrahim, 2009).

Analisis faktor-faktor yang berpengaruh terhadap R/C pada usaha ayam Sentul dilakukan dengan menggunakan persamaan regresi linier berganda sebagai berikut:

$$
\begin{aligned}
Y= & b_{0}+b_{1} X_{1}+b_{2} X_{2}+b_{3} X_{3}+b_{4} X_{4}+b_{5} X_{5}+ \\
& b_{6} X_{6}+b_{7} X_{7}+b_{8} X_{8}
\end{aligned}
$$

Dimana:

$$
\begin{aligned}
& \mathrm{Y}=\text { Efisiensi usaha }(\mathrm{R} / \mathrm{C}) \\
& \mathrm{X}_{1}=\text { Efisiensi Teknis } \\
& \mathrm{X}_{2}=\text { Produktivitas } \\
& \mathrm{X}_{3}=\text { Umur (tahun) } \\
& \mathrm{X}_{4}=\text { Pendidikan (tahun) } \\
& \mathrm{X}_{5}=\text { Pengalaman (tahun) } \\
& \mathrm{X}_{6}=\text { Jumlah anggota keluarga (orang) } \\
& \mathrm{X}_{7}=\text { Jumlah kepemilikan ayam (ekor) } \\
& \mathrm{X}_{8}=\text { Dummy pelatihan, bernilai 1 jika Iya, } \\
& \mathrm{B}=\text { dan bernilai 0 jika lainnya. }
\end{aligned}
$$

Pendugaan parameter dilakukan dengan menggunakan program SPSS versi 16.

\section{HASIL DAN PEMBAHASAN Tingkat Efisiensi Usaha}

Tingkat efisiensi usaha (R/C) yang dicapai pada usaha ayam Sentul disajikan pada Tabel 1.

\section{Tabel 1. Tingkat Efisiensi Usaha}

\begin{tabular}{|c|c|c|c|}
\hline No & $\begin{array}{c}\text { Efisiensi } \\
\text { Usaha }\end{array}$ & $\begin{array}{c}\text { Peternak } \\
\text { (orang) }\end{array}$ & $(\%)$ \\
\hline 1 & $<1$ & 13 & 36,11 \\
\hline 2 & 1 & 1 & 2,78 \\
\hline 3 & $>1$ & 22 & 61,11 \\
\hline \multicolumn{2}{|c|}{ Jumlah } & 36 & 100,00 \\
\hline
\end{tabular}

Sumber: Analisis Data Primer, 2015

Rata-rata $\mathrm{R} / \mathrm{C}$ sebesar 1,32 yang menunjukkan bahwa usaha pemeliharaan ayam
Sentul mampu memberikan keuntungan kepada peternak. Setiap Rp 1 biaya yang dikeluarkan akan memberikan penerimaan sebesar Rp 1,32, sehingga keuntungan yang diperoleh sebesar Rp 0,32 .

Tabel 1 menunjukkan bahwa peternak yang inefisien $(\mathrm{R} / \mathrm{C}<1)$ sebanyak 13 orang $(36,11 \%)$, impas $(\mathrm{R} / \mathrm{C}=1)$ sebanyak 1 orang $(2,78 \%)$, dan efisien $(\mathrm{R} / \mathrm{C}>1)$ sebanyak 22 orang $(61,11 \%)$. Kegiatan penyuluhan, bimbingan teknis dan pelatihan hendaknya difokuskan pada peternak yang inefisien dalam melaksanakan usaha ayam Sentul.

Faktor-faktor yang berpengaruh terhadap R/C dapat dilihat pada Tabel 2.

Tabel 2. Faktor-faktor yang Berpengaruh Terhadap Efisiensi Usaha

\begin{tabular}{|l|c|c|c|}
\hline $\begin{array}{c}\text { Variab } \\
\text { el }\end{array}$ & $\begin{array}{c}\text { Nilai } \\
\text { Parameter }\end{array}$ & $\begin{array}{c}\text { Standar } \\
\text { Deviasi }\end{array}$ & t-hit \\
\hline Interse & $-0,109$ & 0,202 & $-0,540$ \\
$\mathrm{p}$ & $-0,999$ & 1,930 & $-0,518$ \\
$\mathrm{X}_{1}$ & 0,956 & 0,098 & $9,797 *$ \\
$\mathrm{X}_{2}$ & 0,135 & 0,109 & 1,237 \\
$\mathrm{X}_{3}$ & $-0,129$ & 0,087 & $-1,486 * * * *$ \\
$\mathrm{X}_{4}$ & $-0,207$ & 0,058 & $-3,568^{* *}$ \\
$\mathrm{X}_{5}$ & $-0,003$ & 0,062 & $-0,044$ \\
$\mathrm{X}_{6}$ & 0,074 & 0,036 & $2,023^{* * *}$ \\
$\mathrm{X}_{7}$ & 0,068 & 0,029 & $2,334^{* *}$ \\
$\mathrm{X}_{8}$ & & \\
\hline $\mathrm{R}^{2}=0,904$ & \\
F-hit = 31,961** & \\
\hline
\end{tabular}

Sumber: Analisis Data Primer, 2015

Keterangan: $* * * *, * * *, * *, *=$ signifikansi pada $15 \%, 10 \%, 5 \%, 1 \%$

Nilai koefisien determinasi $\left(\mathrm{R}^{2}\right)$ sebesar 0,904 menunjukkan bahwa $\mathrm{R} / \mathrm{C}$ yang dicapai petenak pada usaha ayam Sentul dapat dijelaskan sebesar $90,40 \%$ oleh variabel yang ada di dalam model, sedangkan sisanya sebesar 9,60\% dijelaskan oleh variabel lain yang tidak dimasukkan ke dalam model.

Nilai F-hit sebesar 31,961 pada taraf nyata $0,01 \%$ menunjukkan bahwa seluruh variabel yang ada di dalam model secara simultan berpengaruh sangat signifikan terhadap $\mathrm{R} / \mathrm{C}$ yang dicapai petenak pada usaha ayam Sentul. 


\section{AIMBAR AGRIBISNIS \\ ISSN 2460-4321 \\ Volume 1 - Nomor 3 Juli 2016}

Hasil analisis regresi secara parsial menunjukkan bahwa faktor-faktor yang berpengaruh positif dan signifikan terhadap R/C yang dicapai petenak pada usaha ayam Sentul adalah produktivitas, jumlah kepemilikan ayam dan dummy pelatihan. Faktor-faktor yang berpengaruh negatif dan signifikan terhadap R/C yang dicapai petenak pada usaha ayam Sentul adalah pendidikan dan pengalaman. Efisiensi teknis, umur dan jumlah anggota keluarga tidak berpengaruh signifikan terhadap $\mathrm{R} / \mathrm{C}$ yang dicapai petenak pada usaha ayam Sentul.

Efisiensi teknis tidak berpengaruh signifikan terhadap $\mathrm{R} / \mathrm{C}$ yang dicapai petenak pada usaha ayam Sentul. Koefisien regresi bertanda negatif menunjukkan bahwa peningkatan efisiensi teknis menyebabkan penurunan R/C.

Produktivitas berpengaruh sangat signifikan terhadap $\mathrm{R} / \mathrm{C}$ yang dicapai petenak pada usaha ayam Sentul. Koefisien regresi bertanda positif menunjukkan bahwa peningkatan produktivitas menyebabkan peningkatan R/C. Peningkatan produktivitas menunjukkan adanya peningkatan output sehingga penerimaan yang diperoleh peternak semakin tinggi. Jika biaya diasumsikan tetap, maka peningkatan penerimaan tersebut akan meningkatkan R/C.

Umur tidak berpengaruh signifikan terhadap R/C yang dicapai petenak pada usaha ayam Sentul. Koefisien regresi bertanda positif menunjukkan bahwa penambahan umur peternak akan meningkatkan R/C. Menurut Siahaan (2002) dalam Pambudi, dkk. (2013), pertambahan usia akan menimbulkan tindakan untuk mengelola sistem usahatani supaya lebih baik dan berupaya mendapatkan informasiinformasi baru (pengetahuan berupa inovasi). Hal ini diduga menyebabkan peningkatan produktivitas yang berdampak pada peningkatan $\mathrm{R} / \mathrm{C}$.

Pendidikan berpengaruh signifikan terhadap R/C yang dicapai petenak pada usaha ayam Sentul. Koefisien regresi bertanda negatif menunjukkan bahwa peningkatan pendidikan formal peternak akan menurunkan R/C. Hal ini menunjukkan bahwa upaya peningkatan efisiensi usaha seyogyanya dilakukan melalui pendidikan non formal, misalnya penyuluhan dan pelatihan peternak.

Pengalaman berpengaruh signifikan terhadap R/C yang dicapai petenak pada usaha ayam Sentul. Koefisien regresi bertanda negatif menunjukkan bahwa peningkatan pengalaman peternak akan menurunkan R/C. Menurut Triastono, dkk. (2013), setiap peningkatan satu tahun lama beternak akan menurunkan produktivitas ternak sehingga akan menurunkan pendapatan yang menyebabkan penurunan $\mathrm{R} / \mathrm{C}$.

Jumlah anggota keluarga tidak berpengaruh signifikan terhadap $\mathrm{R} / \mathrm{C}$ yang dicapai petenak pada usaha ayam Sentul. Koefisien regresi bertanda negatif menunjukkan bahwa peningkatan jumlah anggota keluarga akan menurunkan R/C. Menurut Priyanto dan Adiati (2008), semakin banyak jumlah anggota keluarga menyebabkan peternak lebih berorientasi pada usaha di luar pertanian. Hal ini menyebabkan penurunan curahan waktu kerja dan investasi pada usaha ternak yang berdampak pada penurunan efisiensi usaha. Akpan, et al (2011) menyatakan bahwa jumlah tanggungan keluarga yang besar menyebabkan adanya hambatan dalam penggunaan input produksi yang akan berdampak kepada produktivitas.

Jumlah kepemilikan ayam berpengaruh signifikan terhadap $\mathrm{R} / \mathrm{C}$ yang dicapai petenak pada usaha ayam Sentul. Koefisien regresi bertanda positif menunjukkan bahwa peningkatan jumlah kepemilikan ayam menyebabkan peningkatan R/C. Menurut Hartono, dkk. (2013) dan Krisna dan Mansur (2006) dalam Trigestianto, dkk. (2013), peningkatan skala usaha akan meningkatkan penerimaan dan menurunkan biaya produksi. Peningkatan penerimaan yang diikuti dengan penurunan biaya produksi akan meningkatkan $\mathrm{R} / \mathrm{C}$.

Dummy pelatihan berpengaruh signifikan terhadap partisipasi peternak dalam kegiatan kelompok. Koefisien regresi bertanda positif menunjukkan bahwa peternak yang mengikuti pelatihan lebih tinggi $\mathrm{R} / \mathrm{C}$ yang dicapai dibandingkan dengan peternak yang tidak mengikuti pelatihan. Menurut Rohmad (2013), penyuluhan bertujuan untuk memperbaiki manajemen usaha sehingga peternak dapat 


\section{Faktor-Faktor Yang Berpengaruh Terhadap Efisiensi Usaha Ayam Sentul \\ Di Kabupaten Ciamis \\ AGUS YUNIAWAN ISYANTO, SUDRAJAT, MOHAMAD ISKANDAR}

memperbaiki pola pikir, sikap dan perilaku dalam manajemen usaha. Dengan manajemen yang baik diharapkan produktivitas usaha menjadi lebih baik pula.

\section{KESIMPULAN}

(1) Peternak yang inefisien $(\mathrm{R} / \mathrm{C}<1)$ dalam melaksanakan usaha ayam Sentul sebanyak 13 orang $(36,11 \%)$, impas $(\mathrm{R} / \mathrm{C}=1)$ sebanyak 1 orang $(2,78 \%)$, dan efisien $(\mathrm{R} / \mathrm{C}>1)$ sebanyak 22 orang $(61,11 \%)$.

(2) Faktor-faktor yang berpengaruh terhadap efisiensi usaha ayam Sentul adalah produktivitas, jumlah kepemilikan ayam, dummy pelatihan, pendidikan dan pengalaman. Efisiensi teknis, umur dan jumlah anggota keluarga tidak berpengaruh signifikan terhadap efisiensi usaha ayam Sentul.

\section{DAFTAR PUSTAKA}

Aboki, E., A.A.U, Jongur, dan J.I, Onu. 2013. Productivity and Technical Efficiency of Family Poultry Production in Kurmi local Government Area of Taraba State, Nigeria. Journal of Agriculture and Sustainability 4(1): 52-66.

Akpan, S.B., Aya, E.A., Essien, U.A., Akpan, O.D., dan Bassey, N.E., 2011. Analysis of Total Factor Productivity Among Smallholder Vegetable Farmers in AkwaIbom State, Nigeria. Nigerian Journal of Agriculture, Food and Environment, 7(4): 68-74.

Hartono, E.F., Hidayat, N.N., dan Roesdiyanto. 2013. Kinerja Ekonomi Usaha Ayam Sentul di Kabupaten Ciamis. Jurnal Ilmiah Peternakan, 1(3): 865-873.

Ibrahim, Y. 2009. Studi Kelayakan Bisnis. Edisi Revisi. Jakarta: Rineka Cipta.

Iskandar. 2010. Seri Peningkatan Manfaat Sumberdaya Genetik Ternak: Usahatani Ayam Kampung. Bogor: Balai Penelitian Ternak.

Jaelani, A., Suslinawati, dan Maslan. 2013. Analisis Kelayakan Usaha Peternakan Ayam Broiler di Kecamatan Tapin Utara Kabupaten Tapin. Jurnal Ilmu Ternak, 13(2): 42-48.
Muharlien, V.M., dan Nurgiartiningsih, A. 2015. Pemanfaatan Limbah Daun Pepaya Dalam Bentuk Tepung dan Jus Untuk Meningkatkan Performans Produksi Ayam Arab . Research Journal of Life Science 02(01): 17-24.

Pambudi, T.R., Oenteng, E.D., dan Hidayat, N.N. 2013. Analisis Keuntungan dan Rentabilitas Usaha Ayam Niaga Pedaging. Jurnal Ilmiah Peternakan, 1(3): $1128-1135$.

Priyanto, D dan U. Adiati. 2008. Analisis Faktor-faktor Usaha Ternak Domba dalam Mendukung Pola Diversifikasi Usahatani di Pedesaan. Seminar Nasional Teknologi Peternakan dan Veteriner. Bogor: Pusat Penelitian dan Pengembangan Peternakan.

Rohmad. 2013. Analisis Produktivitas Usaha Peternakan Ayam Pedaging Pola Kemitraan Perusahaan Pengelola di Kecamatan Kandat Kabupaten Kediri. Jurnal Manajemen Agribisnis 13(1): 7182.

Santosa, S.I., Setiadi, A., dan Wulandari, R. 2013. Analisis Potensi Pengembangan Usaha Peternakan Sapi Perah dengan Menggunakan Paradigma Agribisnis di Kecamatan Musuk Kabupaten Boyolali. Buletin Peternakan 37(2): 125-135.

Singarimbun, M. 1989. Metode Penelitian Survai. Jakarta: LP3S.

Taufik, D.K., Isbandi, dan Dyah, M. 2013. Analisis Pengaruh Sikap Peternak Terhadap Pendapatan pada Usaha Peternakan Itik di Kelurahan Pesurungan Lor Kota Tegal. JITP 2(3): 201-208.

Triastono, H., Indraji, M., dan Mastuti, S. 2013. Pengaruh Faktor Sosial Ekonomi Terhadap Pendapatan dan Efisiensi Usaha Peternak Kelinci di Kabupaten Banyumas. Jurnal Ilmiah Peternakan 1(1): 25-30.

Trigestianto, M., Nur, S., dan Sugiarto, M. 2013. Analisis Tingkat Kesejahteraan Peternak Sapi Potong di Kabupaten Purbalingga. Jurnal Ilmiah Peternakan 1(3): 1158 -1164.

Utami, H.D., Maharani, B.R.D., dan Seruni, A.P. 2014. The Role Dairy Farming in 


\section{A MIMBAR AGRIBISNIS \\ ISSN 2460-4321}

Volume $1 \bullet$ Nomor $3 \bullet$ Juli 2016

Generating Rural Household Income At

East Java Indonesia. Journal of Applied

Science and Agriculture 9(11): 201-206.

Wibowo, D., Muatip, K., dan Aunurohman, H.

2013. Analisis Efisiensi Usaha dan

Kontribusi Pendapatan Peternak Kelinci

di Kabupaten Banyumas. Jurnal Ilmiah

Peternakan

1(3):

821 